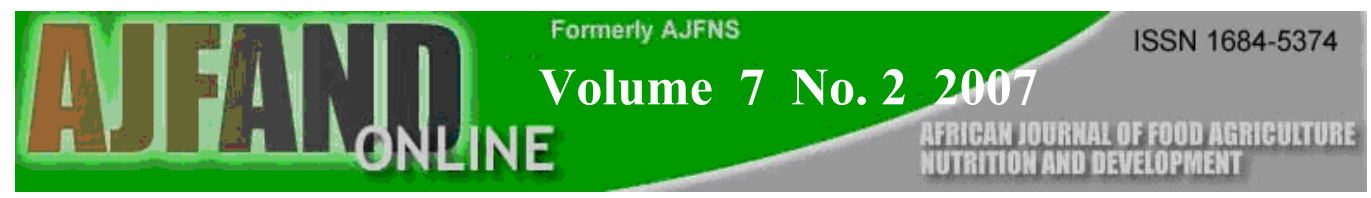

\title{
PROCESSING PROPERTIES OF GRAINS FROM SOME MAIZE CULTIVARS INTRODUCED ON-FARM IN THE $S$ UDANO SAHELIAN ZONE OF CAMEROON
}

\author{
By \\ ${ }^{1 *}$ Kameni A., ${ }^{2 *}$ C. Kouebou and ${ }^{3 *}$ Aboubakar Dandjouma A.K.
}

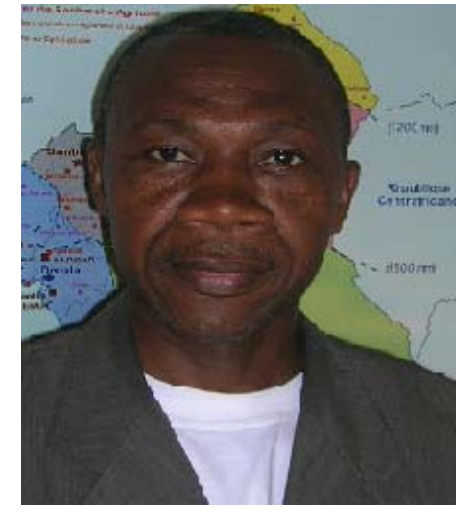

Kameni Anselme

${ }^{1 *}$ Corresponding author:- Email anselmekameni@yahoo.com

Institute of Agricultural Research for Development (IRAD) P.O. Box 2067 Yaounde, Cameroon

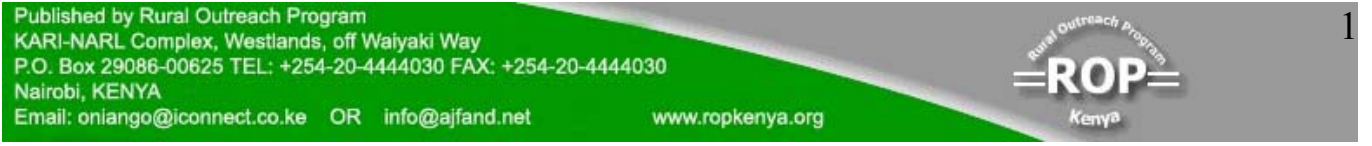




\section{ABSTRACT}

Maize grains from twenty three cultivars developed by research and produced at farm level were evaluated for chemical composition and their ability to produce flour and grit after removal of panicle in wet and dry processes. Sixteen cultivars used for this evaluation were developed by the breeding program of the Institute of Agricultural Research for Development (IRAD) of Cameroon.

The remaining seven originated from CIMMYT, West and Central Africa Maize Network (Wecaman), Ghana and Congo. Flour and grit were produced in wet and dry processes with samples of $10 \mathrm{~kg}$ of grains from each cultivars using available machinery at village level. Wet process of the grains included the removal of the panicle, soaking for 3 hours, drying on the mat for 2 hours, milling, drying of the flour and sieving through different mesh sizes (400 to 800 microns). For the dry milling, whole or pealed grains were simply processed in a hammer mill and the flour fractions separated as with wet milling.

Results indicated some variation in the proximate composition with nine cultivars exhibiting protein contents above $8 \%$. High protein cultivars were in order hybrids 88094X87036, 87036XExp 24 , Acid soil pool yellow, 88094XM131XExp 24 , 87084XM131XExp 24 , Drought pool yellow, Drought pool white, Kassaï SR, Tuxpeno sequia and BSR 81.

PCA analyses revealed that protein and fat contents as factors accounted for over $80 \%$ of intra cultivar variability related to chemical composition. Four major similarity groups of cultivars emerged as striga tolerant with high starch contents, the soft endosperm cultivars, the high fat and high protein cultivars.

Flour and grit yields were cultivar and treatment dependant. Wet milling produced higher flour yields while grit yields were higher when dry milling of pealed grains was done for all cultivars. Cultivars that demonstrated good ability for grit production were ATP SR-Y, Acid soil pool yellow, Drought pool yellow and the hybrids. All cultivars exhibited their ability and suitability for different end uses and this should be taken into account when embarking on large scale maize production.

Key words: maize, cultivars, composition, flour, grits, wet milling,

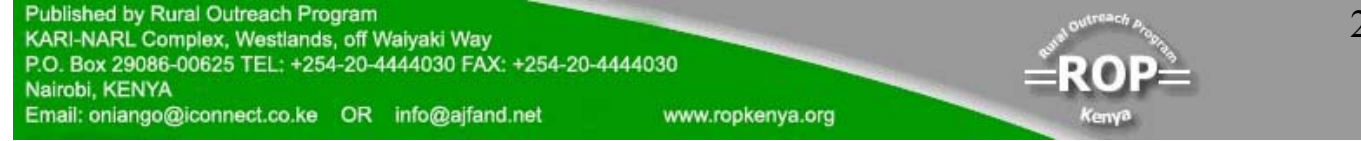




\section{APTITUDES TECHNOLOGIQUES DES GRAINES DE QUELQUES CULTIVARS DE MAÏS (ZEA MAIZE) INTRODUITS EN MILIEU PAYSAN DE LA ZONE SOUDANO-SAHELIENNE DU CAMEROUN}

\section{RESUME}

Les graines de maïs de 23 cultivars développés par la recherche agricole et produites en milieu paysan étaient évaluées pour leur composition chimique et leur aptitude à la production de la farine et du grit ou semoule de maïs. Seize cultivars évalués provenaient du programme de sélection de l'Institut de Recherche Agricole pour le Développement (IRAD, Cameroun) et sept autres provenaient du CIMMYT, du réseau Ouest Africain pour le maïs (WECAMAN), du Ghana et du Congo. Ces graines en échantillons de $10 \mathrm{Kg}$ par cultivars étaient soumises à la mouture sèche et humide après que la panicule et le germe aient été enlevés avec les dégermeurs.

Pour la production du grit en mouture humide les grains dégermés, étaient trempés pendant 3 heures, séchés par étalage sur des nattes pendant 2 heures suivi de la mouture, du séchage de la farine et du tamisage à travers des mailles de 400 à 800 microns. Par mouture sèche, les grains entiers ou dégermés étaient directement soumis à la mouture et la farine séchée et fractionnée.

Les résultats montrent des variabilités importantes dans la composition chimique. Plusieurs cultivars (9) ont des teneurs en protéines supérieures à $8 \%$ en base sèche et sont respectivement les hybrides 88094X87036, 87036XExp 124 , Acid soil pool yellow, 88094XM131XExp 24 , 87084XM131XExp 24 , Drought pool yellow, Drought pool white, Kassaï SR, Tuxpeno sequia et BSR 81.

Les teneurs en matière grasse et protéine comme facteurs expliqueraient $80 \%$ des variabilités observées. Un regroupement à partir de ces facteurs d'affinité donne plusieurs groupes dont un groupe de cultivars tolérants au striga et riche en farine, un groupe à endosperme tendre, un groupe de faible teneur en matière grasse et un groupe de cultivars riches en protéine.

Les rendements de farine et semoule obtenus étaient liés aux traitement et type de cultivars utilisés. La mouture humide améliore des rendements en farine alors que la mouture sèche favorise la production du grit indépendamment des cultivars. Les différents cultivars testés ont montré des aptitudes différentes à la transformation ce qui doit être pris en compte pour des productions à grande échelle.

Mots clés: maïs, cultivars, composition, farine, semoule, mouture humide, 


\section{INTRODUCTION}

Industrial users of maize constitute the largest clients of maize producers. In developing countries where industrial demand for maize is constantly increasing, they import substantial quantities of maize. Their choice is guided by high quality and standards of the maize grains concerned in terms of protein and starch contents as well as technological attributes.

For economically acceptable grit production, a minimum yield of 40 to $45 \%$ is required with less than $1 \%$ fat content. House wife for domestic consumption preferred fine maize flour with about $88 \%$ of its particles measuring less than 500 microns [1]. Poultry feed mills prefer yellow maize with high protein and riboflavin contents.

These observations suggested that there is a need to breed for variety targeted to a given end product such as flour production, protein content, grit yields etc...Continuous efforts of research institutions resulted in the development of many maize cultivars suitable to various agro ecological zones of West and Central Africa [2]. Breeding and selection were based on agronomic features like length of maturing cycle (short, intermediate and long); drought, striga or soil acidity tolerances and disease resistance.

Grain characteristics such as colour, texture, and acceptance by farmers were also considered. Over 20 maize cultivars were released to farmers [3]. However, major differences in physico-chemical characteristics of corn kernels and their relationship with the quality of dry-milled maize flour had been reported [4]. This work was intended to evaluate the grains of some selected maize cultivars produced on farmer's fields for their ability for quality flour and grit production.

\section{MATERIALS AND METHODS}

Maize grains: Sixteen cultivars used for this evaluation were developed by the breeding program of Institute of Agricultural Research for Development (IRAD) of Cameroon. The remaining seven originated from CIMMYT, West and Central Africa Maize Network (Wecaman), Ghana and Congo (Table 1).

Quality seeds of those cultivars were planted on 0.25 ha plots on farm following recommended agronomic practices. Production conditions were those normally practiced by farmers and no attempt was made to use isolation techniques to ensure quality and genetic purity of the cultivars produced. Maize grains encountered on local markets are produced under these very conditions. At maturity, maize was allowed to dry on the field, then manually harvested, shelled and the grains used.

Flour and grits were produced in wet and dry processes [5] with $10 \mathrm{~kg}$ of grains from each cultivars using available equipments (Gondard peeling machine and hammer 
mill) powered by electric engines. Wet process of the grains included the removal of the panicle, soaking for 3 hours, drying on the mat for 2 hours, milling, drying of the flour and sieving through different mesh sizes (400 to 800 microns). For the dry milling, whole or pealed grains were simply processed in a hammer mill and the flour fractions separated as with wet milling.

\section{Chemical analyses}

The AOAC methods were used [6]. Samples were taken for : dry matter by the atmospheric oven method, fat by Soxhlet hexane extraction, total protein by the kjeldahl method and total fibber by extraction. Total starch was estimated from the differences between dry matter and the rest of the constituents.

\section{Statistical analysis}

The GLM procedure of the SAS was used [7]. Mean separation was done by the Duncan multiple range method. Principal Component Analyses (PCA) were used to classify cultivars into similarity groups.

\section{RESULTS}

The proximate composition of grains of the 23 maize varieties used are presented in Table 2. Dry matter contents varied from 88.35 to $94.25 \%$ for the hybrid 88094 X87036 and Cam Inb STR-1 respectively. Nine cultivars had their dry matter contents higher than $90 \%$. Crude protein contents were 5.24 and $9.11 \%$ for Advanced NCRE and hybrid $87036 \mathrm{XExp}_{1} 24$ respectively. Ten cultivars exhibited crude protein contents of more than $8 \%$. However, observed protein content for Obapanpa was 7.96 $\%$ lower than $9.73 \%$ when grown in isolation.

PCA analyses (Figure 1) revealed that protein and fat contents as factors accounted for over $80 \%$ of intra cultivar variability related to chemical composition. Many major similarity groups emerged from left to right confirming major differences among cultivars. The group on the right comprises mostly cultivars tolerant to striga and rich in flour. The middle groups include most of the soft endosperm cultivars and the left groups are made up of protein rich cultivars. From top to bottom fat rich cultivars are on the upper lines while low fat cultivars are on the lower lines. 

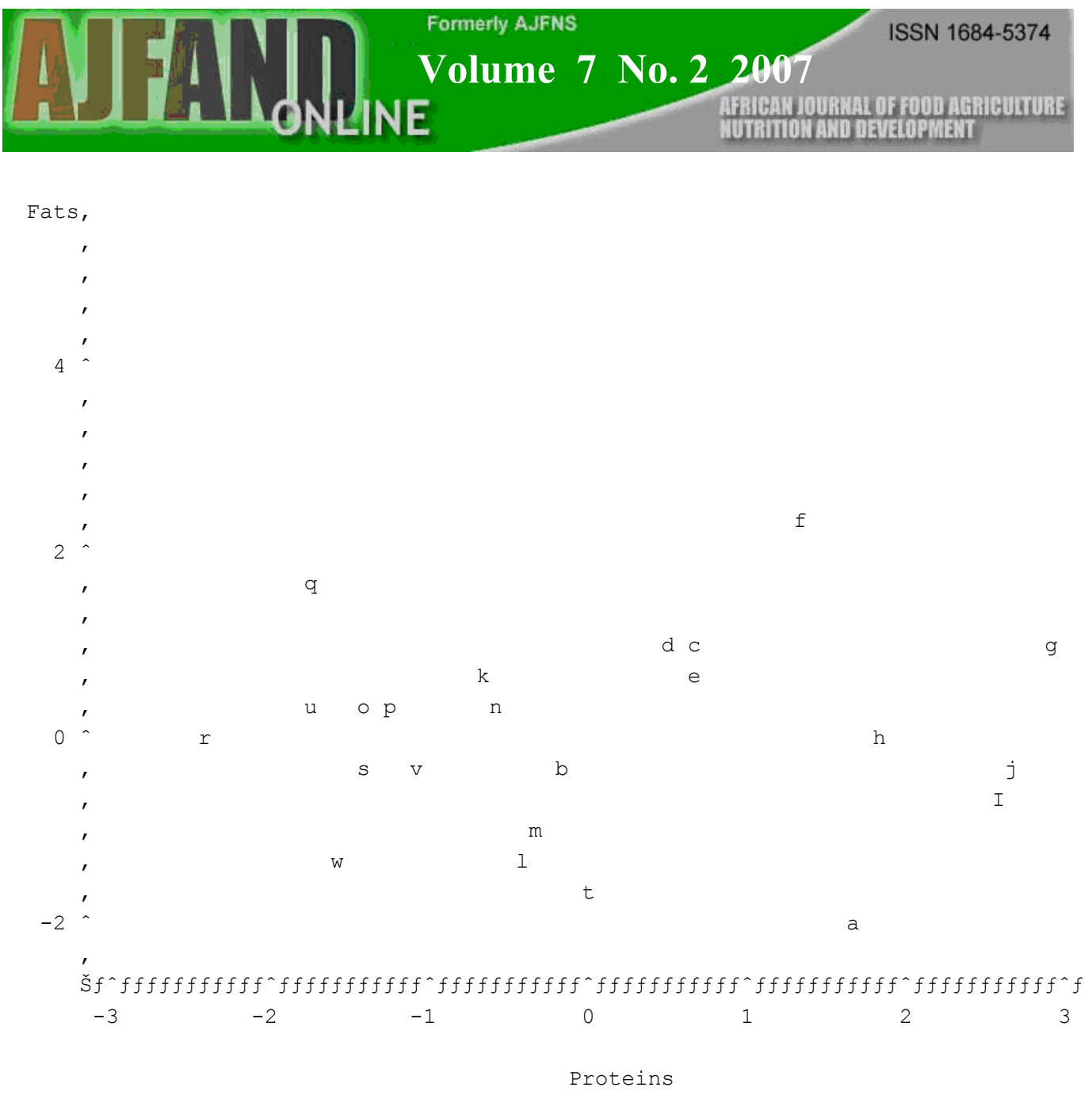

Figure 1: Distribution of maize cultivars according to their composition (Plot of Protein*Fat)

\section{Codes:}
a: TZEE SR-W
g: K9350
m: Kasai SR
s: $87036 x M 131 \times \operatorname{Exp}_{1} 24$
b: CMS 2019
h: Cam Inb STR1.
n: OBATAMPA
t: $870365 \mathrm{Exp}_{1} 24 \times 88069$
c: CMS 8501
i: STR-Y
o: Tuxpeno Sequia
u: $88094 \times 87036$
d: CMS 9015
j: NCRE
p: Drought Pool Yellow
v: $87036 x \operatorname{Exp}_{1} 24$
e: CMS 8704
k: ATP SR-Y
q: Drought Pool white
w: $88094 x M 131 \times \operatorname{Exp}_{1} 24$
f: CMS 8806
l: BSR 81
r: Acid Soil Pool Yellow

Wet milling increased flour production of all cultivars (Figure 2) compared to dry milling which increased grit production (Figures 3). Cultivars TZEE SR-W, CMS 2019, CMS 9015, BSR 81, Kasai SR, Obatanpa, and all the hybrids (except $88094 \times 87036$ with less than $30 \%$ grit yield) demonstrated poor ability for grit production in wet milling. 
Intermediate cultivars for grit production with yields between 30 and $35 \%$ were CMS 8501, CMS 8704, CMS 8806, Advanced NCRE, Acid soil pool yellow, and the hybrid 8809x87036. Only four cultivars exhibited grit yields of over $35 \%$ (ATP SRY, Tuxpeno Sequia, Drought poll yellow and Drought pool white). For flour production, the leading cultivars were Obatanpa, TZEE SR-W, BSR 81 and all the hybrids. In dry milling peeled grain produced grit with yields ranging from 40 to 48 $\%$.

Leading cultivars for grit production were ATP SR-Y, CMS 8704, Tuxpeno Sequia and Acid soil pooled yellow. ATP SR-Y and Advanced NCRE were less affected by the wet or dry milling treatments given and demonstrated good ability for flour and grit production.

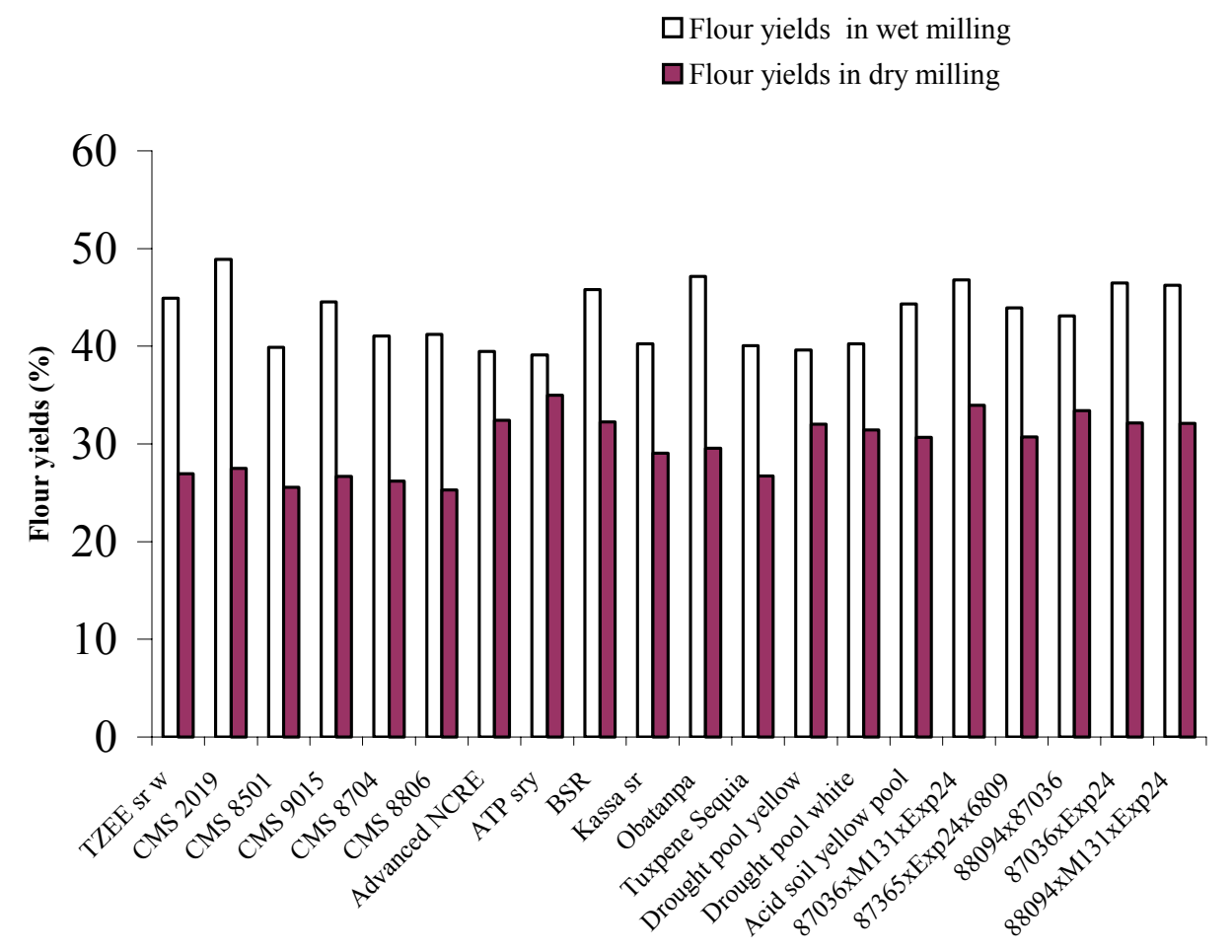

Maize varieties

Fig. 2 Flour production of various maize cultivars in wet and dry milling

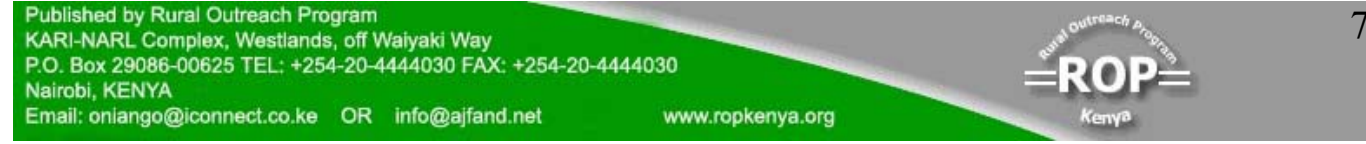




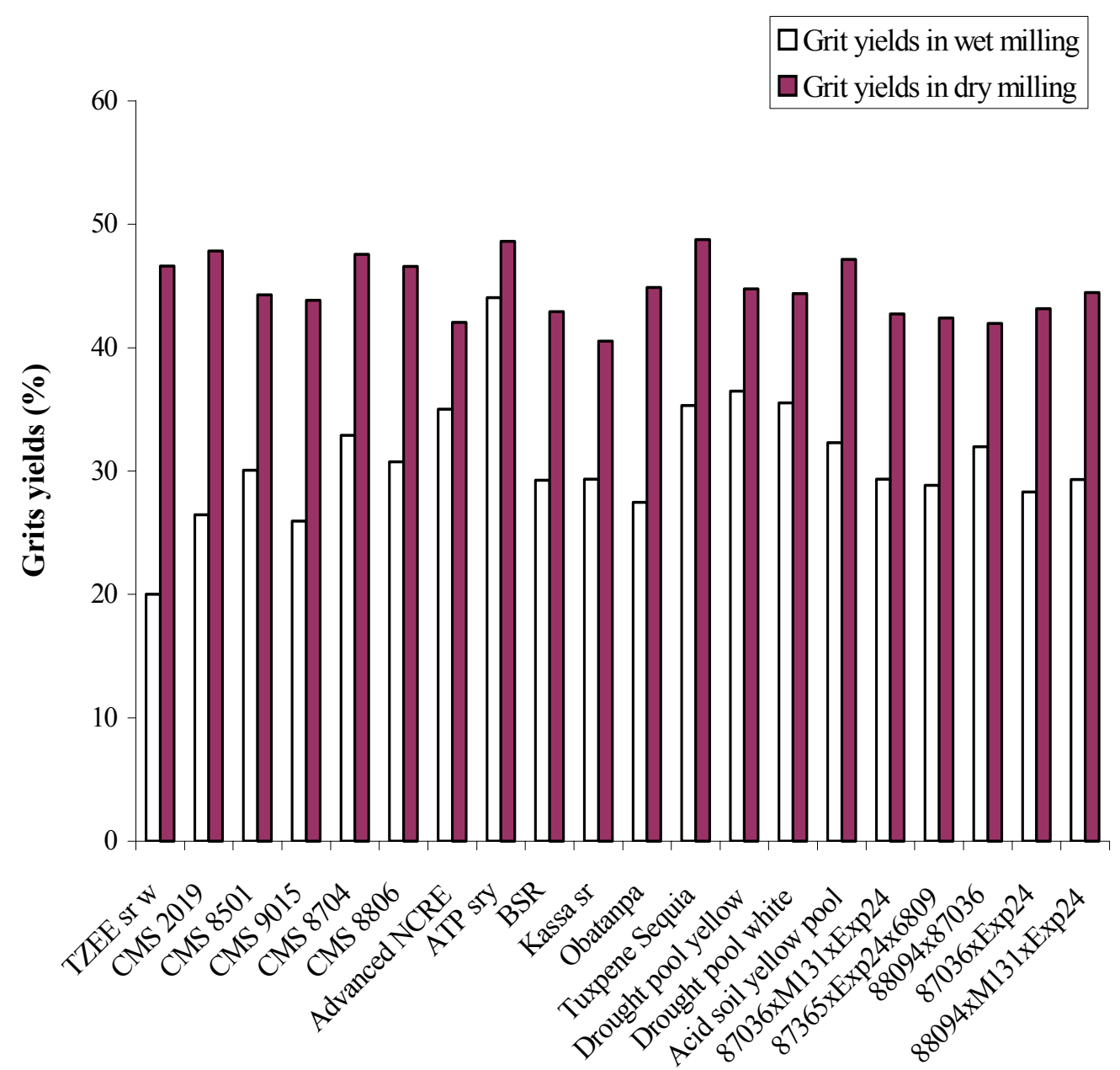

Maize cultivars

Fig. 3 Grit Production of various maize cultivators in wet dry milling

\section{DISCUSSION}

The contents of the main components (fat, protein and starch ) of maize grain were cultivar dependant and this could explain the variability observed in the chemical composition of the various maize cultivars. The high dry mater contents observed in some cultivars (over $90 \% \mathrm{DM}$ ) is a good indicator for grain storability. The differences observed in their chemical composition confirmed the specificity of each cultivar. These variations which are normal and pertinent to maize cultivars have already been mentioned in Benin and with American Hybrids [8, 9]. 
Fat and protein contents showed variations due to cultivars while the similarity in starch contents indicates narrow genetic variability for starch content. The values for chemical composition obtained are within the range indicated by early results $[10$, 11]. However, observed protein content for Obapanpa was $7.96 \%$ lower than $9.73 \%$ when grown in isolation [12]. Obatanpa is QPM very sensitive to contamination in open pollinating situation as is the case in farmers' fields. High protein contents makes this cultivar attractive for animal feed particularly mono-gastric and human consumption.

The technological attributes portrayed by maize cultivars is a possible response to simulation of the processing of maize from small farms which represent over $90 \%$ of producers in the sudano sahelian Africa. Flour and grit yields are indicators of the possible output of such processing units working with the machinery currently available. Grit yields obtained in dry milling are quite favourable and can satisfy the need of agro industries ( $>40 \%)$. However, this process is economically costly. Hard grains cause a lot of damages on the hammers and the steel mesh against which they crash before breaking into small particles.

A consequence is a rapid wearing of machine which on the long run becomes coast inefficient due to frequent repairs. Wetting the grains renders them tender and increases their friability and ability to break into coarse particles when hit by the hammer. This explains the increases observed in flour yield under wet milling compared to dry milling. The low grit yields of the wet process confirmed the complains generally mentioned by agro industrial users. Among the cultivars developed, only one exceeded grit yield of $40 \%$ the acceptable limit for industrial commercial production. The soft endosperm cultivars exhibited the lowest yields for grit production. This could be explained by the soft nature of their grains They may be better recommended for flour production.

Although the Gondard pealing machine coupled to a hammer mill are the most available machinery currently used in towns and villages in Central Africa, they were not very suitable for quality grit production. The major handicap was its inability to remove the germs so as to reach the acceptable limit of fat contents in grit. The presence of fat in flour adversely affect its shelf live under prolong storage due to rancidity. To avoid prolong storage of flour, house wives preferred to only mill the daily quantity of maize needed. This is a major factor limiting maize flour sales in retail outlets. Germ removal should be improved upon through the use of more appropriate machinery for proper flour and grit production [13].

The adoption of various maize cultivars developed is a driving force of the current maize revolution in West and Central Africa. Initially, breeders laid emphasis on agronomic characteristics in terms of grain yields, soil and climatic tolerances. These factors along side processing properties need to be combined to provide cultivars that give satisfaction to both farmers and grain users. The low grit yields obtained in wet milling should equally be considered in the breeding programme so as to improve on

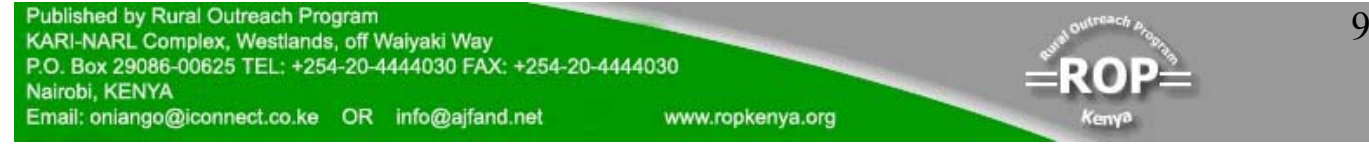


these aspects. Most cultivars developed were suitable as food maize in terms of chemical composition.

From maize grain technological attributes and chemical composition, the user can be very specific and only request the cultivars suitable for his business. High protein cultivars are recommended for animal feed. For grit production leading cultivars were ATP SR-Y, Tuxpeno Sequia, Dought pool yellow and Drought Pool White. Based on grit fat content, only 2 hybrids out of all the cultivars introduced (87036xM131 xExp 24 and $88094 \times 87036)$ met the specifications of brewers with the machinery used. However if germ removal is improved, all the cultivars will be suitable for quality grit production in dry milling.

\section{CONCLUSION}

The evaluation of the suitability of maize cultivars for processing into flour and grit showed that flour and grits yields obtained were cultivar and treatment dependant. Flour yield was high in wet milling while grit yield was high in dry milling of pealed grains. The pealing machine was not very suitable for germ removal and grits had fat contents above $1 \%$ for most cultivars. The cultivars exhibited their ability and suitability for different end uses.

\section{ACKNOWLEDGMENT}

This study wase sponsored by WECAWAN and the African Development Bank ADB through The Institute of Agricultural Research for Development IRAD, Cameroon. 
Table 1: Agronomic characteristics of some selected maize cultivars developed

\begin{tabular}{|c|c|c|c|c|c|}
\hline Names & Pedigree & Origins & $\begin{array}{l}\text { Grain } \\
\text { texture }\end{array}$ & $\begin{array}{l}\text { Grain } \\
\text { colour }\end{array}$ & $\begin{array}{l}\text { Maturity } \\
\text { cycles }\end{array}$ \\
\hline TZEE SR-W & Tuxpeno Sequia & Wecaman & Dent & White & Extra early \\
\hline CMS 2019 & Suwan 1 x pop 43 SR & IRAD & Flint/dent & White & Intermediate \\
\hline CMS 8501 & TZB х рор 49 & IRAD & Dent/flint & White & Intermediate \\
\hline CMS 9015 & Pool $16 \mathrm{DT}^{*}$ & Wecaman & Dent & White & Early \\
\hline CMS 8704 & Suwan 1 SR & Wecaman & Flint & Yellow & Intermediate \\
\hline CMS 8806 & DMR-ESR-Y & Wecaman & Flint & Yellow & Early \\
\hline K9350 & Pop 43 SR x 9450 & IRAD & Dent & white & Early \\
\hline Cam inb-STR-1 & Suwan 1x Pop 43 SR & IRAD & Flint & Yellow & Early \\
\hline STR-Y & Suwan 1x Pop 43 SR & IRAD & Flint & Yellow & Early \\
\hline Advanced NCRE & $\begin{array}{l}\text { Inbred from various } \\
\text { issues }\end{array}$ & IRAD & Dent/flint & white & Intermediate \\
\hline ATP-SR-Y & TLPB x CMS 04 & IRAD & Flint & Yellow & Intermediate \\
\hline BSR-81 & Local x TZLSR-w & IRAD & Dent/Floury & White & Early \\
\hline Kassai SR & Pop 32 x pop 43 SR & Congo & Flint/dent & White & Intermediate \\
\hline Obatanpa & EV8663QPM & Ghana & Flint/dent & White & Intermediate \\
\hline Tuxpeno Sequia & Tuxpeno & CIMMYT* & Dent & White & Intermediate \\
\hline Drought pool yellow & $\begin{array}{l}\text { Pool } 16 \text { Dt x Maka x } \\
\text { FBC6 }\end{array}$ & IRAD & Flint & Yellow & Intermediate \\
\hline Drought pool white & $\begin{array}{l}\text { Pool16Dt } x \text { tuxpeno } \\
\text { Sequia (2) }\end{array}$ & IRAD & Dent & White & Intermediate \\
\hline Acid soil yellow & SA3xATPxCMS36 (2) & IRAD & Flint & Yellow & Intermediate \\
\hline 87036XM131XEXp 24 & Pop32xTZMSRxPOP43 & IRAD & Flint/dent & White & Intermediate \\
\hline 87365XP24X88069 & Pop32xPop43xTZMSR & IRAD & Flint/dent & White & Intermediate \\
\hline $88094 X 87036$ & Pop43xPop32xTZMSR & IRAD & Flint & White & Intermediate \\
\hline 87036XExp 124 & Pop32xPop43TZMSR & IRAD & Flint & White & Intermediate \\
\hline 88094XМ131ХЕXр 24 & Pop43xTZMSRxPOP32 & IRAD & Flint & White & Intermediate \\
\hline
\end{tabular}

* Obtained from CIMMYT 
Table 2: Proximate composition (\% DM) and Germ weight percentage of grains from some selected maize cultivars produced by local farmers.

\begin{tabular}{|c|c|c|c|c|c|c|c|}
\hline Varieties & $\begin{array}{l}\text { Dry } \\
\text { Mater }\end{array}$ & $\begin{array}{l}\text { Crude } \\
\text { Protein }\end{array}$ & Fat & Ash & $\begin{array}{l}\text { Crude } \\
\text { Fiber }\end{array}$ & Starch & $\begin{array}{l}\text { \% } \\
\text { Germ }\end{array}$ \\
\hline TZEE SR-W & $93.25^{\mathrm{g}}$ & $7.77^{\mathrm{h}}$ & $3.99^{\mathrm{cd}}$ & $0.70^{\mathrm{a}}$ & $2.09^{\mathrm{k}}$ & 85.45 & $9.44^{\mathrm{a}}$ \\
\hline CMS 2019 & $92.50^{\mathrm{g}}$ & $7.52^{\mathrm{g}}$ & $3.50^{\mathrm{ab}}$ & $1.40^{\mathrm{g}}$ & $2.63^{\circ}$ & 84.95 & $11.73^{\mathrm{j}}$ \\
\hline CMS 8501 & $90.00^{\text {efg }}$ & $6.03^{\mathrm{bc}}$ & $4.30^{\mathrm{f}}$ & $1.40^{\mathrm{g}}$ & $1.74^{\mathrm{f}}$ & 86.53 & $10.60^{\mathrm{e}}$ \\
\hline CMS 9015 & $88.53^{\mathrm{abc}}$ & $6.21^{\mathrm{cd}}$ & $4.20^{\mathrm{ef}}$ & $1.47^{\mathrm{h}}$ & $2.14^{1}$ & 85.98 & $13.69^{\mathrm{m}}$ \\
\hline CMS 8704 & $89.07^{\text {abcde }}$ & $5.77^{\mathrm{b}}$ & $4.21^{\mathrm{ef}}$ & $1.40^{\mathrm{g}}$ & $1.87^{\mathrm{h}}$ & 86.75 & $11.63^{\mathrm{j}}$ \\
\hline CMS 8806 & $90.22^{\mathrm{fg}}$ & $6.27^{\mathrm{d}}$ & $5.11^{\mathrm{i}}$ & $1.65^{\mathrm{i}}$ & $2.35^{\mathrm{m}}$ & 84.62 & $12.43^{1}$ \\
\hline CMS K9350 & $92.97^{\mathrm{g}}$ & $5.95^{\mathrm{ab}}$ & $5.41^{\mathrm{j}}$ & $1.06^{\mathrm{d}}$ & $2.36^{\mathrm{m}}$ & 85.22 & $10.12^{\mathrm{c}}$ \\
\hline Cam Inb STR-1 & $94.25^{\mathrm{h}}$ & $6.65^{\mathrm{e}}$ & $4.62^{\mathrm{h}}$ & $1.07^{\mathrm{d}}$ & $2.02^{\mathrm{j}}$ & 85.64 & $10.96^{\mathrm{g}}$ \\
\hline STR-Y & $93.25^{\mathrm{g}}$ & $5.86^{\mathrm{ab}}$ & $4.22^{\mathrm{ef}}$ & $0.93^{\mathrm{c}}$ & $2.45^{\mathrm{n}}$ & 86.54 & $11.38^{\mathrm{i}}$ \\
\hline Advanced NCRE & $92.55^{\mathrm{g}}$ & $5.24^{\mathrm{e}}$ & $4.47^{\mathrm{g}}$ & $0.83^{\mathrm{b}}$ & $2.01^{\mathrm{j}}$ & 87.45 & $10.64^{\mathrm{e}}$ \\
\hline ATP SR-Y & $88.88^{\mathrm{abcd}}$ & $6.92^{\mathrm{ab}}$ & $4.19^{\mathrm{ef}}$ & $1.37^{\mathrm{g}}$ & $1.27^{\mathrm{a}}$ & 86.25 & $10.79^{\mathrm{f}}$ \\
\hline BSR 81 & $88.62^{\mathrm{abc}}$ & $8.23^{\mathrm{a}}$ & $4.00^{\mathrm{cd}}$ & $0.73^{\mathrm{a}}$ & $1.86^{\mathrm{h}}$ & 85.18 & $11.48^{\mathrm{i}}$ \\
\hline Kasai SR & $89.50^{\text {cdef }}$ & $8.24^{\mathrm{f}}$ & $3.89^{\mathrm{c}}$ & $0.93^{\mathrm{c}}$ & $2.01^{\mathrm{j}}$ & 84.93 & $11.99^{\mathrm{k}}$ \\
\hline Obatanpa & $88.50^{\mathrm{ab}}$ & $7.96^{\mathrm{i}}$ & $4.28^{\mathrm{f}}$ & $1.31^{\mathrm{f}}$ & $1.93^{\mathrm{i}}$ & 86.45 & $10.79^{\mathrm{f}}$ \\
\hline Tuxpeno Sequia & $89.25^{\text {abcdef }}$ & $8.24^{\mathrm{i}}$ & $4.10^{\mathrm{de}}$ & $1.35^{\mathrm{fg}}$ & $1.72^{\mathrm{f}}$ & 84.59 & $9.74^{\mathrm{b}}$ \\
\hline Drought pool yellow & $88.81^{\mathrm{abcd}}$ & $8.58^{\mathrm{j}}$ & $4.58^{\mathrm{gh}}$ & $1.08^{\mathrm{d}}$ & $1.30^{\mathrm{b}}$ & 84.46 & $12.31^{1}$ \\
\hline Drought pool white & $90.51^{\mathrm{g}}$ & $8.24^{\mathrm{i}}$ & $4.02^{\text {cd }}$ & $2.02^{\mathrm{j}}$ & $1.53^{\mathrm{d}}$ & 84.19 & $11.08^{\mathrm{gh}}$ \\
\hline Acid soil yellow pool & $89.48^{\text {bcdef }}$ & $9.03^{\mathrm{k}}$ & $3.50^{\mathrm{ab}}$ & $1.60^{\mathrm{i}}$ & $1.35^{\mathrm{c}}$ & 84.52 & $10.33^{\mathrm{d}}$ \\
\hline 87036XM131XEXp 124 & $89.67^{\text {defg }}$ & $8.62^{\mathrm{j}}$ & $3.89^{\mathrm{c}}$ & $1.31^{\mathrm{f}}$ & $1.55^{\mathrm{d}}$ & 84.63 & $11.16^{\mathrm{h}}$ \\
\hline 87036x $\operatorname{Exp}_{1} 24 \times 88069$ & $88.99^{\mathrm{abcd}}$ & $7.53^{\mathrm{g}}$ & $3.54^{\mathrm{b}}$ & $0.83^{\mathrm{b}}$ & $2.07^{\mathrm{k}}$ & 86.03 & $11.06^{\mathrm{gh}}$ \\
\hline $88094 \times 87036$ & $88.35^{\mathrm{a}}$ & $9.12^{\mathrm{k}}$ & $4.09^{\mathrm{de}}$ & $1.46^{\mathrm{h}}$ & $1.77^{\mathrm{g}}$ & 83.56 & $10.19^{\mathrm{c}}$ \\
\hline 87036XExp 24 & $89.06^{\text {abcde }}$ & $9.11^{\mathrm{k}}$ & $4.47^{\mathrm{g}}$ & $1.05^{\mathrm{d}}$ & $1.67^{\mathrm{e}}$ & 83.7 & $11.07^{\mathrm{gh}}$ \\
\hline 88094XM131XEXp 24 & $88.73^{\mathrm{abcd}}$ & $8.75^{\mathrm{j}}$ & $3.38^{\mathrm{a}}$ & $1.17^{\mathrm{e}}$ & $1.77^{\mathrm{g}}$ & 84.93 & $11.90^{\mathrm{k}}$ \\
\hline
\end{tabular}

*Means in column with the same letter are not significantly different $(\mathrm{P}<0.05)$ 


\section{REFERENCES}

1. Kameni, A., Doassem, J. and .Mayake. A. Etude de la faisabilité technico économique d'unités semi industrielles de transformation du maïs au Nord Cameroun. MEAVSB Garoua, Cameroun. 2000; 250pp

2. Badu -Apraku B., Dialo A.O., Fajemisin J.M. and MAB Fakerode Progress in breeding for drought tolerance in tropical early maturing maize for semiarid zone of West and Central Africa. In : G.O. Edmeades, M. Banziger, H.R. Mikelson and C.B. Pena-Vildivia (eds) Developing drought low N tolerant maize. Proceedings of a symposium; March 1996 CMMYT. El Bata Mexico, Mexico, D.F. CYMMIT. 1997.

3. IRA-NCRE. Annual report. Institute of Agricultural Research. National Cereal Research and Extension Project. IRA. Cameroon. Nkolbisson Yaounde. 1990.

4. Nago M., Akissoë N., Matencio F, and C Mestres End use quality of some African corn kernels. 1. Physico-chemical characteristics of kernels and their relationship with the quality of "liftin", a traditional whole dry-milled maize flour from Benin. J of Agric. and Food Chem. 1997; 28:215-222.

5. Mestres C., Louis Alexandre A., Matencro F. and A. Lahlou. Dry milling properties of maize. Cereal chemistry. 1991; $68: 51-56$.

6. AOAC. Official Methods of Analysis. Association of official analytical chemists Washington D.C. 1999.

7. SAS Institute Inc. SAS user's guide: Basis version $5^{\text {th }}$ edition. Cary, NC.: SAS Institute Inc. 1985; $1290 \mathrm{pp}$

8. Earle, F. R., Curtis, J. J., and J.E. Hubbard Composition of component parts of cornKernel. Cereal chemistry 1946; 23:504 - 511.

9. Mestres C., Nago M., Hounhouigan J. and Akissoë N. Qualité comparée des graines de maïs béninois issus des écotypes locaux et des cultivars améliorés : mise au point des tests rapides de sélection. In Maize revolution in West and Central Africa. Ed B. Badu-Apraku. Wecaman, IITA Ibadan Nigeria. 2003; 440-446.

10. Johnson L. A. Corn: production, processing and utilization. In Handbook of cereal science and technology. K. J. Lorenz et Kulp K. eds. New York, USA, Dekker inc., 1991; 55-131.

11. Asiedu, J.J. La transformation des produits agricoles en zone tropicale. Approche technologique. CTA Karthala. 1991; 191-216.

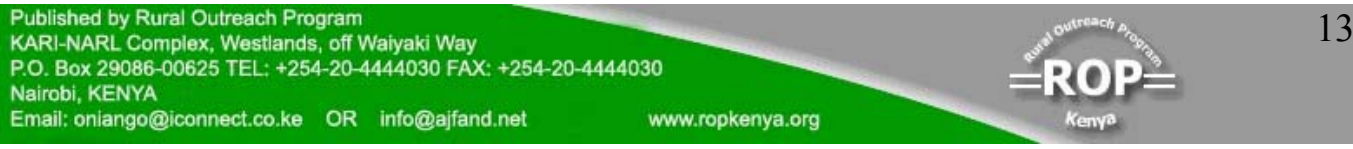


12. Sallah P.Y.K., Obeng-Anti K., Asiedu E.A., Ewoll M.B. and BD Dzah. Recent advances in the development and promotion of quality protein maize in Ghana. In Maize revolution in West and Central Africa. Ed B. Badu-Apraku. Wecaman, IITA Ibadan. . 2003; 410-424.

13. Hounhouigan D.J., Sekpe H. G., Kayodé A.P., Mestres C. and C M Nago. Mechanization of maize degerming for mawe production. In Maize revolution in West and Central Africa. Ed B. Badu-Apraku. Wecaman, IITA Ibadan Nigeria. 2003; 453-462. 